\title{
УДК 316.61:111.8
}

DOI https://doi.org/10.26661/hst-2021-8-85-02

\section{СТАНОВЛЕННЯ І РОЗВИТОК ПАРАДИГМИ САМОАКТУАЛІЗАЦІЇ ОСОБИСТОСТІ ТА ЇЇ ПЕРЕОСМИСЛЕННЯ У КОНТЕКСТІ СУЧАСНОСТІ}

\author{
(С) ЛИСЕНКО С. О. \\ Придніпровська державна академія фізичної культури і спорту (Дніпро, Україна) \\ E-mail: lysenko630@gmail.com \\ ORCID: https://orcid.org/0000-0002-4222-7049 \\ Придніпровська державна академія фізичної культури і спорту 49094, \\ Дніпро, Україна \\ Prydniprovsk State Academy of Physical Culture and Sport 10, Naberezhna Peremohy str., 49094, Dnipro, Ukraine
}

\begin{abstract}
Анотація.
Постановка проблеми. У самому загальному вигляді проблема становлення і розвитке парадигми самоактуалізації особистості здійснюється у контексті творів А. Маслоу і пов'язана з виявленням проблем метамотивації, креативності, вищих потреб і вищих цінностей, які складають суть здорової самоактуалізації теорії людського буття. Становлення і розвиток парадигми самоактуалізації особистості та ії переосмислення у контексті сучасності пов'язана з сучасними методами, засобами і технологіями гуманістичної психології, методів психоаналізу з метою формування цілісної особистості. Останні дослідження та аналіз публікацій. Деякі аспекти парадигми самоактуалізації особистості та іiі переосмислення здійснено у контексті сучасних технологій, що вивчаються фахівцями з аналітичної психології, соціології, філософії, нейронауки. Мета статті - концептуалізація нових підходів до аналізу самоактуалізації особистості та їі переосмислення у контексті сучасності, щоб допомогти сформувати цілісну особистість, щоб стати такими, якими справді хоче сучасне суспільство, а для цього слід глибше осягнути закономірності розвитку людини і суспільства, власного характеру, що сприятиме пошуку шляху до найкращого втілення та пізнання самих себе. Завдання дослідження: 1) проаналізувати теоретичну парадигму А. Маслоу як прихильника «теорії людського буття» чи «позитивної психології; 2) дослідити феномен самоактуалізації як парадигми реалізації свого власного потенціалу. Серед методів ми використовуємо методи гуманістичної психології, зокрема екзистенційно-гуманістичного напрямку, які роблять виразний акцент на гуманістичних мотивах. Основна частина статті. Представлено дослідження парадигми А. Маслоу як прихильника «теорії людського буття» чи «позитивної психології, що розвивається у швидко плинному світі. Розкрито умови становлення цілісної особистості та шляхів досягнення її самоактуалізації. У даній статті аналізується доповнена ієрархія потреб Маслоу, яка грунтується на останніх наукових дослідженнях і $є$ тією основою, що допоможе людині розібратися у своїх поведінкових моделях і зрозуміти, як теперішній спосіб життя допомагає зростанню й трансцендентності. Розкрито феномен самоактуалізації як парадигми реалізації свого власного потенціалу, для чого людині необхідно передусім задовольнити базові потреби - у безпеці, стабільності, визначеності, прогнозованості, зв’язності, послідовності й довірі до оточення. Висновки дослідження. Доведено, що самоактуалізація та трансцендентність можуть існувати у цілковитій гармонії. Вихід до нових рубежів людської природи вимагає справжнього поєднання уявлень про самоактуалізацію, передбачає ситуацію захищеності. Сучасна школа повинна стати місцем для формування благоговіння, самоактуалізації, виховання цілісних особистостей.

Ключові слова: самоактуалізація особистості, А. Маслоу, метамотивації, креативність, вищі потреби, вищі цінності, теорія «людського буття», трансцендери, здорова самоактуалізація
\end{abstract}

Постановка проблеми у загальному вигляді та їі зв’я зок із важливими науковими чи практичними завданнями

Актуальність теми дослідження у тому, що більшість людей чула про ієрархію потреб А. Маслоу, де піраміду увінчує самоактуалізація особистості, проте, як вона діє сьогодні та якими наповнюється характеристиками в умовах сучасності для багатьох невідомо. У трактуванні деяких філософів запроваджене поняття А. Маслоу постає індивідуалістичним та егоїстичним. Але наприкінці життя автор прийшов до висновку, що здорова самоактуалізація - це шлях до трансцендентності. Поняття самоактуалізації індивіда - ключове у світі творів А. Маслоу. Воно є i потребою, i здатністю i самоціллю людини. I кажучи про поняття креативності по Маслоу, не можна не визначити його головне поняття - самоактуалізацію.

Говорити про це тим важливо, що саме А. Маслоу практично не виділяв креативності як окремого якості особистості: «Створюється враження, ніби у людства є єдина кінцева мета, віддалена мета, до якої прагнуть всі люди. Різні автори називають іiі по-різному: самоактуалізація, самореалізація, інтеграція, психічне здоров'я, 
індивідуалізація, автономія, креативність, продуктивність, - але всі вони згодні у тому, що все це синоніми реалізації потенцій індивіда, становлення людини у повному сенсі цього слова, становлення тим, ким вона може стати».

А. Маслоу писав: «Я виділив креативність в окрему характеристику лише для демонстрації, розуміючи, що вона невіддільна від інших характеристик самоактуалізованої людини. Таким чином, будь-яка самоактуалізована людина - креативна за своєю сутністю, а тому поняття самоактуалізації займає в його концепції центральну роль [20].

Виділення невирішених раніше частин загальної проблеми, котрим присвячується означена стаття

У даній статті ми спробуємо конкретизувати уявлення А. Маслоу про нові рубежі людства, розкрити таємниці його текстів пізнього періоду й поєднати сукупність думок, що є найкращими висновками про найвищі обрії людської природи, що накопичилися відтоді, та корелюються 3 найкращими характеристиками особистості - креативності, інтелекту, психологічного відчуття.

У центрі уваги статті-потенціал людини у площині пошуку правди, краси, пізнання, любові, призначення, благоговіння та інших трансцендентних переживань, що глибоко пов'язані із природою людини. Саме вони можуть допомогти людині зробити зміни у житті та наблизитися до трансцендентності повсякденного існування. Але для цього необхідно надзвичайно пильно придивитися до глибини свого «Я», щоб уповні відчути насиченість людського буття.

Нині надзвичайно багато хто почувається глибоко нереалізованим у цьому хаотичному й розрізненому світі, який заохочує до гонитви за грошима, владою, величчю і навіть щастям, що виступають вершиною людських прагнень. Ми видираємося на верхівку статусної ієрарxiї, домагаємося фінансової успішності, навіть подеколи почуваємося щасливими, та все одно переживаємо глибоку невдоволеність, так як жадаємо сильнішого зв'язку з іншими і зі своїм сумбурним «Я».

Аналіз останніх досліджень і публікацій, 3 яких започатковано розв'язання даної проблеми і на які спирається автор

У своїх творах А. Маслоу вважав, що схильні до самоактуалізації люди - це яскраві особистості, які реалізують свій потенціал, проте аби допомогти людині вповні розкрити свій потенціал, треба розглянути іiі цілісно. У публікації 1961 року він писав, що самоактуалізація видається йому перехідною метою, кроком за межі виходу «Я» особистості, виходу за грані своєї особистості.

А. Маслоу вважав, що прагнення до самоактуалізації - зміцнення зв'язків зі світом свого «Я» і задоволення базових потреб як основний крок на цьому шляху, у результаті чого самоактуалізація спрощує процес злиття з великим цілим. Посилаючись на гуманістичну революцію, А. Маслоу пояснив, що гуманістична психологія почала піднімати на поверхню таємниці «справжніх людських переживань», потреб, цілей і цінностей, до яких належать вищі цінності - потреба у любові, дружбі, гідності, самоповазі, індивідуальності та самореалізації. Проте концентрація на дуже вузькому сегменті свого характеру нерідко змушує від них відвернутися.

Люди так часто шукають зовнішнього визнання, що не розвивають тих прекрасних чеснот, які мають всередині, і до того ж рідко присвячують час задоволенню своїх найглибших потреб у якомога ціліснішій, зорієнтованій на зростання потреб формі. Упродовж останніх років А. Маслоу розробив серію вправ для виходу за межі его й збільшення регулярності життя у «Б-вимірі»- вимірі «чистого буття». Крім того, він працював над питаннями комплексної психології та філософії природи людини й суспільства. Не випадково, багато його однодумців писали, що люди ще не раз відкриватимуть для себе Маслоу, доки не осягнуть усього багатства його думок.

Сьогодні дуже багато людей прагнуть трансцендентності без здорової інтеграції інших потреб, що шкодить їхньому здоровому потенціалу. Концептуалізація нових підходів до аналізу самоактуалізації особистості та її переосмислення у контексті сучасності доповнена мудрими, глибокими й людяними за суттю ідеями гуманістичної психології, останніми науковими здобутками цілої низки царин, зокрема позитивної, соціальної, еволюційної психології, соціології, філософії, кібернетики, нейронауки. 31930 по 1970-і pp. сформувалася група мислителів Альфред Адлер, Джеймс Б'юджентал, Шарлотта Бюлер, Артур Комбе, Віктор Франкл, Еріх Фромм, Юджин Джендлін, Карен Горні, Сідні Журар, Джим Клі, Рональд Девід Лейнг, Родло Мей, Клар Мустакас, Карл Роджерс, Дональд Сніг, Ентоні Сутіч, які вже на той час бачили обмеженість напрямів експериментальної психології, біхевіоризму, психоаналізу. 
Науковцям вдавалося виявити, що ці дисципліни не дають належної оцінки особистості, нехтують величезним потенціалом людства площині творчості, духовності та філантропії. Називаючи себе «третьою слою», ці вчені намагалися поєднати здобутки традиційних підходів і з'ясвувати положення про те, що означає почуватися людиною і як це усвідомлення проливає світло на змістовне життя.

Мета та формування цілей статті (постановка завдання).

Мета статті - концептуалізація нових підходів до аналізу самоактуалізації особистості та їі переосмислення у контексті сучасності з метою допомогти прийняти себе, а, отже, стати такими, якими справді хоче стати сучасна людина, а для цього слід глибше осягнути закономірності власного характеру, що сприятиме пошуку шляху до найкращого втілення самих себе.

\section{Завдання дослідження:}

1) проаналізувати теоретичну парадигму А. Маслоу як прихильника «теорії людського буття» чи «позитивної психології;

2) дослідити феномен самоактуалізації як парадигми реалізації свого власного потенціалу.

\section{Методологія дослідження.}

Серед методів ми використовуємо методи гуманістичної психології, зокрема екзистенційногуманістичного напрямку, які роблять виразний акцент на гуманістичних мотивах, як-от: автентичністю усвідомлення співчутливих соціальних дій, що найсприятливіші для розвитку суспільства, включаючи духовність, вихід за межі «Я», цілісність, сприйняття парадоксів людського буття. Відповідно до методів аналізу гуманістичної психології здоровою особистістю вважається така, що постійно прагне свободи, відповідальності, самоусвідомлення, сенсу, обов'язку, особистісного розвитку, зрілості, інтеграції до змін. Мартін Селігман, продовжуючи ідеї А. Маслоу, вважав, що дослідження психологічного самопочуття повинно відбуватися «заради чого варто жити».

Сучасних фахівців об'єднує думка про те, щоб зрозуміти й підтримувати здорову мотивацію та здорове життя, що включає гуманістичні методи, в основі яких висока інтенсивність позитивних емоцій, позитивна суб'єктивна оцінка свого життя загалом, позитивне суб'єктивне відчуття фізичного здоров’я, здатність адаптувати своє середовище до своїх потреб, відчуття контролю над власним життям, теплі відносини з людьми, що гуртуються на довірі, почуття власної цінності, почуття компетентності у процесі виконання складних завдань, здатність протистояти тиску з боку суспільства, постійне прагнення до розвитку й самовдосконалення, залученість у повсякденну діяльність, почуття значущості, цінності та гідності власного життя, натхнення, що означає стати людиною, щоб жити змістовно. Ці характеристики людини пов'язані 3 появою у житті нового сенсу, зростання, самовдосконалення та самореалізації. Нова ієрархія потреб людини може слугувати для психологічної царини корисною організаційною структурою, напрямом до здоров’я, розвитку й трансцендентності.

Важливим для аналізу є використання принципу ентропії, яке поширюється на всі системи опрацювання інформації, тобто на мозок, нервову систему та психологічні процеси людини. Виживання всіх біологічних організмів, зокрема й людей, залежить від здатності до ефективного подолання внутрішньої ентропії. Поза сумнівом, у житті завжди буде певний рівень психологічної ентропії. Суспільству ніколи не взяти своє середовище під повний контроль, а те, що здавалося передбачуваним, постійно змінюється.

Певний рівень стресу й непрогнозованості це нормально, адже ми прагнемо певної захищеності у всесвіті, який за своєю природою тимчасовий i плинний, а йому притаманна певна суперечність. I хоча чимало змін у роботі мозку адаптивні-вони виправдані у контексті виявлення загроз і усього організму, так як за це доводиться за це платити. Коли рівень внутрішньої ентропії стає занадто високим, людині доводиться розробляти альтернативні стратегії мінімізації загроз та задоволення базових потреб. Якщо ж нічого не допомагає, то система поступово втрачає здатність до адаптації й зрештою руйнується.

Виклад основного матеріалу дослідження 3 обгрунтуванням отриманих наукових результатів

1. Теоретична парадигма А. Маслоу як прихильника «теорії людського буття» чи «позитивної психології»

А. Маслоу був прихильником теорії «психології буття» - царини, у межах якої відбувається систематичне дослідження цілей, а не засобів: цільових переживань (зв'язків), цільових цінностей (краса, правда, справедливість), цільових процесів (ефективне сприйняття дійсності та новизна оцінки), кінцевих цілей (найвища мета чи призначення), а також ставлення до людей і до самоцілі, а не засобів досягнення мети, яке він охрестив «буттєвою любов’ю». 
Інтерес до «психології буття» А. Маслоу називавав «позитивною психологією» чи ортопсихологією, а згодам представників «третьої сили» почав називати «психологами гуманістичного спрямування», сама царина якої офіційно утворилася у 1961 р. Теорію потреб А. Маслоу часто зображують у вигляді строгої послідовності, у контексті якої, задовольнивши один набір запитів, людина неначе назавжди припиняє перейматися тими чи іншими потребами. Життя розуміється як комп'ютерна гра, у контексті якої здійснивши одну потребу людина не повертається до попередньої потреби. Але А. Маслоу все своє життя був адептом теорії психології розвитку, наголошуючи на тому, що людина завжди перебуває у процесі становлення, а «внутрішнє ядро» людини складається всього лише 3 «потенційних можливостей», а не остаточного втілення своїх очікувань.

Маслоу давав чітко зрозуміти, що людина завжди перебуває у процесі становлення, а «внутрішнє ядро» людини складається всього лише 3 потенційних можливостей, а не остаточного втілення очікувань. Учений чітко дав зрозуміти, що дозрівання людини - це тривалий процес, а $\dddot{11}$ розвиток - це не раптове стрибкоподібне явище, а нерідко це «два кроки вперед і один крок назад». Один аспект теорії А. Маслоу не отримав належної уваги: його ієрархія потреб є організаційною структурою для різних станів душі, тобто способів бачення світу та інших людей. За словами вченого, кожна потреба, якщо ії не задовольняти, зумовить своєрідний світогляд, філософію та відповідне сприйняття майбутнього.

Він вважав, що більшість людей частково задоволена й водночас частково незадоволена всіма базовими потребами. Існує ще одне поширене хибне судження, буцімто потреби відрізані одна від одної й між ними немає чіткої взаємозалежності. Потреби людини утворюють не дихотомічну структуру, а інтегральну ієрархію, вони спираються одна на одну. А, отже, повернення до потреб нижчого рівня нікуди не зникає, а в цьому контексті слід розглянути не тільки як патологію чи хворобу, а як необхідний чинник цілісності організму, а також передумову для існування й функціонування вищих потреб. Якщо людина цілісна, то усі іiі базові потреби не просто реалізовані, а разом узяті, допомагають їй зростати і втілювати у життя найвищі цілі та цінності [с. 24].

А. Маслоу стверджував, що не тільки базові потреби коливаються впродовж життя, але й у способі їх задоволення також можуть бути значні культурні та особистісні відмінності. Точний порядок ієрархії потреб людини залежить від культури, людини й змінюється впродовж життя, проте він стверджував, що всі потреби можна розділити на два основні класи - дефіцитарність і зростання, які слід інтегрувати, щоб досягти цілісності. Мотивацією дефіцитарних запитів, які А. Маслоу називав «Д-потребами», стає невдоволеність (відсутність їжі, безпеки, симпатії, приналежності чи самооцінки), що спотворює дійсність. Чим вищий ступінь невдоволення потреб, тим сильніше ми спотворюємо дійсність, щоб адаптувати свої очікування та виробити захисні механізми, щоб уберегтися від болю, який нам завдає такий дефіцит.

Мудрість для зростання дає нам змогу чіткіше бачити реальність, пов'язану з тим, щоб зробити свій вибірк на користь цілісності та інтегрованості і захистити себе як особистість. Попри численні труднощі, А. Маслоу вважав, що до самоактуалізації здатні всі, адже люди керуються дефіцитною мотивацією, в основі якої захищеність і зростання, а це два фундаменти становлення цілісної особистості. Отже, самоактуалізація особистості спирається на три конкретні потреби - пізнання, любов і призначення, що представляють суть справжнього погляду на самоактуалізацію, між якими існує справжня синергетична взаємодія, що дає змогу зростати й ставати цілісними особистостями. Трансцендентність спирається на надійний фундамент захищеності й зростання та відношення до свого «Я» 3 почуттям зв'язку 3 усім людством. Ця нова ієрархія потреб - це не просто теорія людської природи, а теорія людського буття, в основі якої $є$ можливість вийти за межі своїх складників, стати чимось більшим, ніж їхня сукупність, дати раду аксіомам буття на свій лад.

2. Самоактуалізація як парадигма реалізації свого власного потенціалу

А. Маслоу відмічав, що для того, щоб мати змогу вповні реалізувати свій потенціал, людині необхідно передусім задовольнити базові потреби. Сучасна наука чітко свідчить про те, що непрогнозованість серйозно впливає на життя, як ми можемо створити. Потреба у безпеці та супутні потреби в стабільності, визначеності, прогнозованості, зв'язності, послідовності й довіри до оточення - це підгрунтя для задоволення всіх інших запитів. Коли у людини $\epsilon$ надійний фундамент, вона здатна ризикувати, розглядати нові концепції й способи життя, але 
водночас мати змогу стати такою, якою справді вона хоче бути. Відсутність такого підмурка може негативно позначитися на зростанні особистості, iii розвитку та сенсу життя. Зерова трансцендентність - це новітнє явище, наслідок гармонійної цілісної інтеграції нашого «Я» заради виховання доброго суспільства [с. 254.].

А. Маслоу припустив, що трансцендерів метамотивують вищі ідеали та цінності, які виходять за межі задоволення базових потреб і реалізації свого неповторного «Я». Такі метамотивації охоплюють відданість певному покликанню, що слугують найвищими цінностями, тобто Б-цінностями буття. А. Маслоу склав їх перелік, до яких відносяться добро, краса, справедливість, правда, змістовність, жвавість, неповторність, довершеність, простота, елегантність, цілісність. Названі вище цінності не застосовувалися ні для чого іншого, вони не слугували інструментом досягнення якоїсь мети. Вчений вважав, що запровадження метапотреб необхідне для того, щоб мати змогу вповні розкрити людський потенціал, який буде зростати, що люди провинні надавати своєму існуванню змістовності, які значно свідоміше знаходять мотивацію у Б-цінностях, як-от досконалість, правда, добро, єдність, піднесення над дихотомією, Б-розваги. Завдяки реалізації метапотреб люди сприймають світ цілісніше, вони схильні до синергії - інтрапсихічної, міжособистісної, внутрішньо культурної; частіше підносяться над его, мають виразну здібність до новаторства, до відкриття нового, вбачають красу довкілля, потенціал чеснот, притаманних людській природі.

Більшість людей здобуває знання, щоб знизити рівень таємничості і тривожності, вони діють ефективно, впевнено й стрімко, схильні вважати себе носіями таланту, інструментами надособового. Більшою мірою вони схильні до духовного i релігійного, їм не так складно вийти за межі свого «Я», ідентичності й самоактуалізації, вони тонкіше відчувають Б-вимір, із ними частіше стаються граничні переживання. Характер людини набуває зрілості, зростає й рівень вищого рівня оплати («метаплата») i нагороди («метанагорода»), окрім грошей і похвали, а до роботи вони відносяться як до хобі, тому що вони люблять свою діяльність, яка є частиною їх задоволення.

Якщо розглядати характеристики трансцендерів цілісно, то вони утворюють довершений світогляд, котрому притаманна справжня інтеграція особистості на всіх рівнях. Трансцендер вміє орієнтуватися у Д-вимірі і Б-вимірі життя. Світогляд теорії Z сповнений благоговіння, краси, подиву, пізнання, відкритості, відвертості, цілісного сприйняття, Б-любові, чесної оцінки своїх здібностей, виходу за межі-Его, синергії, внутрішньої мотивації, єдності спонуки у вигляді найвищих життєвих цінностей.

Світогляд теорії $Z$ ідентичний теорії розвитку, стадіям інтегральності его та його генеративності, конструктивного розвитку та цілісності. За словами Крамер, мудрі люди вміють бачити позитивне і негативне, поєднувати одне з одним i формувати людяніше, цілісніше уявлення про своє «Я» в усій його крихкості та вразливості, інтегрують здатність до самоаналізу з глибкою турботою про міжлюдські відносини та формування цілісних особистостей, сприяють розвитку цілісного потенціалу внутрішньої природи людини.

\section{Висновки.}

Таким чином, у процесі проведеного аналізу, доведено, що самоактуалізація та трансцендентність можуть існувати у цілковитій гармонії. Вихід до нових рубежів людської природи вимагає справжнього поєднання уявлень про самоактуалізацію, що передбачає ситуацію захищеності. Сучасна школа повинна стати місцем для формування благоговіння, самоактуалізації, виховання цілісних особистостей.

Тому не слід нехтувати можливостями, дотичними до самоактуалізації та трансцендентності. Завдяки самоактуалізації можливо вдосконалити себе і сформувати добре суспільство й самих себе. Покращення соціуму починається зсередини, зі зміни уявлень про людську природу.

\section{Список використаних джерел:}

1. Bilohur Vlada, Andriukaitiene Regina \& MakieshynaYyuliia. Educational policy in the field of sport during the COVID-19 pandemic: challenges, threats, development trends. Humanities studies: Collection of Scientific Papers. Zaporizhzhia: Zaporizhzhia National University, 2021.7 (84). P. 65-74.

2. Воронкова В.Г. Концепции взаимосвязи человека, сознания, разума в контексте виртуально-информационного пространства. Philosophy and cosmology. Kyiv: ISPC, 2014 (vol. 14) C. 170-182.

3. Воронкова В. Г. The civil society as a paradigm, concept and social construct fhilosophical discourse.Philosophy and cosmology. Kyiv: ISPC, 2015. Vol.15. С.198-215. Режим доступу: http://ispcjournal.org/journals/2016/11.pdf 
4. Воронкова В, Андрюкайтене Р., Кивлюк О., Романенко Т., Рижова И. Концептуализация smart-общества и smart-технологий в контексте развития современной цивилизации. Mokslas ir praktika: aktualijos ir perspektyvos Taptautiné mokslinè-praktinė konferencija. 2017. C.11-12.

5. Воронкова Валентина, Кивлюк Ольга, Нікітенко Віталіна, Рижова Ірина.

Stem-освіта як фактор становлення і розвитку smart-суспільства. 2017. C. 23-24

6. Voronkova Valentina, Cherep Alla, Nikitenko Vitalina, Andriukaitiene Regina. Conceptualization of digital reality expertise in conditions of stochaic insurance: nonlinear methodology. Humanities studies: Collection of Scientific Papers. Zaporizhzhia: Zaporizhzhia. National University, 2019. 2(79). Р. 182-195..

7. Кауфман Скотт. За межами піраміди потреб. Новий погляд на самореалізацію / пер. з англ. Анна Марковська. Київ: Лабораторія, 2021, 400 с.

8. Nikitenko Vitalina. Evolution and further development of the real world in the conditions of technological changes in the context of socio-philosophical discourse. Humanities studies: Collection of Scientific Papers. Zaporizhzhia: Zaporizhzhia. National University, 2020. 4(81). P. 60-73.

9. Nikitenko Vitalina, Andriukaitiene Regina, Punchenko Oleg. Formation ofsustainable digital economical concept: challenges, threats, priorities. Humanities studies: Collection of Scientific Papers. Zaporizhzhia: Zaporizhzhia. National University, 2019. 1(78). P.140-153.

10. Melnik Victoria. Agile-management 3.0 concept as a factor of technological progress development in the digital society. Humanities studies: Collection of Scientific Papers. Zaporizhzhia: Zaporizhzhia. National University, 2019. 1(78). P. 130-139.

11. Nesterenko Olena, Oleksenko Roman. Social philosophical reflection of the individual legal education philosophy as the basis for the democratic society functioning. Humanities studies: Collection of Scientific Papers. Zaporizhzhia: Zaporizhzhia. National University, 2020. 4(81). P. 165-181..

12. Punchenko Oleg, Voronkova Valentyna \& Vodop'yanov Pavel. Health care as a global problem of humanity and its relationship with other global problems. Humanities studies: Collection of Scientific Papers. Zaporizhzhia: Zaporizhzhia. National University, 2021. 7 (84). P. 39-47. doi: https://doi.org/10.26661/hst-2020-7-84-05

13. Punchenko Oleg, Punchenko Natalia. Basic strategic technology of intellectual duality of humanity in information technology. Humanities studies: Collection of Scientific Papers. Zaporizhzhia: Zaporizhzhia. National University, 2019. 2 (79). P. 95-114.

14. Рижова I. С. Сутність і зміст дизайну. Гуманітарний вісник Запорізької державної інженерної академії. 2012. Випуск 51. С. 206-216.

15. Рижова I C. Формування потреб та інтересів в дизайнерській діяльності. Гуманітарний вісник Запорізької державної інженерної академії. 2010. Випуск 51. С. 247-258.

16. Рижова I. С. Методи, принципи, підходи до аналізу дизайнерської культури як умови гармонізації відносин людини, природи, суспільства. Гуманітарний вісник Запорізької державної інженерної академії. 2016. Випуск 66. С. 192-205.

17. Рижова I. С..Концепція розвитку дизайнерської творчості як специфічного способу самореалізації особистості і вільного освоєння світу. Гуманітарний вісник Запорізької державної інженерної академії.2013. Випсук 55. С.219-234

18. Стародубець В. С. Саморозвиток особистості керівника як лідера інновацій в умовах системних змін. Humanities studies: Collection of Scientific Papers. Zaporizhzhia: Zaporizhzhia. National University, 2020. 6 (83). P. 181-197.

19. Cherep A., Voronkova V., Andriukaitiene R, Nikitenko V. The concept of creative digital technologies in the tourism business in the conditions of digitalization. Humanities studies: Collection of Scientific Papers. Zaporizhzhia: Zaporizhzhia. National University, 2020. 5 (82). P. 196-209.

\section{REFERENCES}

1. Bilohur, Vlada, Andriukaitiene, Regina \& Makieshyna,Yyuliia (2021). Educational policy in the field of sport during the COVID-19 pandemic: challenges, threats, development trends. Humanities studies: Collection of Scientific Papers. Zaporizhzhia: Zaporizhzhia National University. 7 (84). 65-74.

2. Voronkova, V. H. (2014). Koncepcii vzaimosvyazi cheloveka, soznaniya, razuma v kontekste virtual'no-informacionnogo prostranstva. Philosophy and cosmology. Kyiv: ISPC, vol. 14. 170-182.

3. Voronkova, V. H. (2015). The civil society as a paradigm, concept and social construct fhilosophical discourse. Philosophy and cosmology. Kyiv: ISPC. Vol.15. 198-215. Режим доступу: http://ispcjournal.org/journals/2016/11.pdf

4. Voronkova, V, Andryukajtene, P., Kivlyuk, O., Romanenko, T. \& Rizhova, I. (2017). Konceptualizaciya smart-obshchestva i smart-tekhnologij v kontekste razvitiya sovremennoj civilizacii. Mokslas ir praktika: aktualijos ir perspektyvos Taptautinè mokslinè-praktinė konferencija. 11-12.

Становлення і розвиток парадигми самоактуалізації особистості та її переосмислення у контексті сучасності 
5. Voronkova, Valentina, Kivlyuk, Ol'ga, Nikitenko, Vitalina \& Rizhova, Irina (2017). Stem-osvita yak faktor stanovlennya i rozvitku smart-suspil'stva. 23-24.

6. Voronkova, Valentina, Cherep, Alla, Nikitenko, Vitalina \& Andriukaitiene, Regina (2019). Conceptualization of digital reality expertise in conditions of stochaic insurance: nonlinear methodology. Humanities studies: Collection of Scientific Papers. Zaporizhzhia: Zaporizhzhia. National University. 2(79). P. 182-195.

7. Kaufman Skott (2021). Za mezhami piramidi potreb. Novij poglyad na samorealizaciyu / per. z angl. Anna Markovs'ka. Kiïv: Laboratoriya. $400 \mathrm{~s}$.

8. Nikitenko, Vitalina (2020). Evolution and further development of the real world in the conditions of technological changes in the context of socio-philosophical discourse. Humanities studies: Collection of Scientific Papers. Zaporizhzhia: Zaporizhzhia. National University. 4(81). 60-73.

9. Nikitenko, Vitalina, Andriukaitiene, Regina \& Punchenko, Oleg (2019). Formation ofsustainable digital economical concept: challenges, threats, priorities. Humanities studies: Collection of Scientific Papers. Zaporizhzhia: Zaporizhzhia. National University. 1(78). 140-153.

10. Melnik, Victoria (2019). Agile-management 3.0 concept as a factor of technological progress development in the digital society. Humanities studies: Collection of Scientific Papers. Zaporizhzhia: Zaporizhzhia. National University. 1(78). 130-139.

11. Nesterenko, Olena \& Oleksenko, Roman (2020). Social philosophical reflection of the individual legal education philosophy as the basis for the democratic society functioning. Humanities studies: Collection of Scientific Papers. Zaporizhzhia: Zaporizhzhia. National University. 4(81). 165-181.

12. Punchenko, Oleg, Voronkova, Valentyna \& Vodop'yanov, Pavel (2021). Health care as a global problem of humanity and its relationship with other global problems. Humanities studies: Collection of Scientific Papers. Zaporizhzhia: Zaporizhzhia. National University.7 (84). 39-47. doi: https://doi.org/10.26661/hst-2020-7-84-05

13. Punchenko, Oleg \& Punchenko, Natalia (2019). Basic strategic technology of intellectual duality of humanity in information technology. Humanities studies: Collection of Scientific Papers. Zaporizhzhia: Zaporizhzhia. National University. 2 (79). 95-114.

14. Rizhova, I. S. (2012). Sutnist' i zmist dizajnu. Gumanitarnij visnik Zaporiz'koï derzhavnoï inzhenernoï akademiï. Vipusk 51. 206-216.

15. Rizhova, I. S. (2010). Formuvannya potreb ta interesiv v dizajners'kij diyal'nosti. Gumanitarnij visnik Zaporiz'koï derzhavnoï inzhenernoï akademiï. Vipusk 51. 247-258.

16. Rizhova,I. S. Metodi, principi, pidkhodi do analizu dizajners'koï kul'turi yak umovi garmonizaciï vidnosin lyudini, prirodi, suspil'stva. Gumanitarnij visnik Zaporiz'koï derzhavnoï inzhenernoï akademiï. 2016. Vipusk 66. $192-205$.

17. Rizhova, I. S. (2013). Koncepciya rozvitku dizajners'koï tvorchosti yak specifichnogo sposobu samorealizaciï osobistosti i vil'nogo osvoennya svitu. Gumanitarnij visnik Zaporiz'koï derzhavnoï inzhenernoï akademiï. Vipsuk 55. 219-234

18. Starodubec', V. S. (2020). Samorozvitok osobistosti kerivnika yak lidera innovacij v umovakh sistemnikh zmin. Humanities studies: Collection of Scientific Papers. Zaporizhzhia: Zaporizhzhia. National University. 6 (83). 181-197.

19. Cherep, A., Voronkova, V., Andriukaitiene, R \& Nikitenko, V. (2020). The concept of creative digital technologies in the tourism business in the conditions of digitalization. Humanities studies: Collection of Scientific Papers. Zaporizhzhia: Zaporizhzhia. National University. 5 (82). 196-209.

LYSENKO SVITLANA - Candidate of Philosophic Sciences, Associate Professor at the Social and Humanitarian Sciences Department (Dnipro, Ukraine)

E-mail: lysenko630@gmail.com

ORCID: https://orcid.org/0000-0002-4222-7049

\title{
FORMATION AND DEVELOPMENT OF THE PARADIGM OF SELF-ACTUALIZATION OF PERSONALITY AND ITS RETHINKING IN THE CONTEXT OF MODERNITY
}

\begin{abstract}
.
Formulation of the problem. In its most general form, the problem of formation and development of the paradigm of self-actualization of personality is carried out in the context of A. Maslow's works and is associated with identifying problems of metamotivation, creativity, higher needs and higher values. The formation and development of the paradigm of self-actualization of the individual and its rethinking in the context of modernity is associated with modern methods, tools and technologies of humanistic psychology, methods of psychoanalysis in order to form a holistic personality.
\end{abstract}

(C) Лисенко, Світлана, 2021 
Recent researches and analysis of publications. Some aspects of the paradigm of self-actualization of the individual and its rethinking are carried out in the context of modern technologies studied by specialists in analytical psychology, sociology, philosophy, neuroscience. The purpose of the article is to conceptualize new approaches to the analysis of selfactualization of personality and its rethinking in the context of modernity, to help to form a holistic personality, to become what modern society really wants, and to understand the patterns of human development and society finding a way to the best incarnation and self-knowledge. Objectives of the study: 1) to analyze the theoretical paradigm of A. Maslow as a supporter of the "theory of human existence" or "positive psychology; 2) to explore the phenomenon of self-actualization as a paradigm of realization of one's own potential. Among the methods we use the methods of humanistic psychology, in particular the existential-humanistic direction, which place a clear emphasis on humanistic motives. The main part of the article. A study of A. Maslow's paradigm as a supporter of the "theory of human existence" or "positive psychology, which is developing in a rapidly flowing world, is presented. The conditions for the formation of a holistic personality and ways to achieve its self-actualization are revealed. This paper analyzes Maslow's complementary hierarchy of needs, which is based on the latest scientific research and is the basis that will help a person understand their behavioral patterns and understand how the current way of life helps the growth and transcendence. The phenomenon of self-actualization as a paradigm of realization of one's own potential is revealed, for which a person must first of all satisfy basic needs security, stability, certainty, predictability, coherence, consistency and trust in the environment. Research findings. It is proved that self-actualization and transcendence can exist in complete harmony. Reaching the new frontiers of human nature requires a real combination of ideas about self-actualization, provides a situation of security. The modern school should become a place for the formation of reverence, self-actualization, education of holistic individuals.

Key words: self-actualization of personality, A. Maslow, metamotivations, creativity, higher needs, higher values, theory of "human existence", transcenders, healthy self-actualization

ЛЫСЕНКО С. А. - кандидат философских наук, доцент, кафедра социально-гуманитарных наук Приднепровская академия физической культуры и спорта (Днепр, Украина)

E-mail: lysenko630@gmail.com

ORCID: https://orcid.org/0000-0002-4222-7049

\section{СТАНОВЛЕНИЕ И РАЗВИТИЕ ПАРАДИГМЫ САМОАКТУАЛИЗАЦИИ ЛИЧНОСТИ И ЕЕ ПЕРЕОСМЫСЛЕНИЕ В КОНТЕКСТЕ СОВРЕМЕННОСТИ}

Постановка проблемы. В самом общем виде проблема становления и развития парадигмы самоактуализации личности осуществляется в контексте произведений А. Маслоу и связана с выявлением проблем метамотивации, креативности, высших потребностей и высших ценностей, которые составляют состваляют суть здоровую самоактуализации человеческого бытия. Становление и развитие парадигмы самоактуализации личности и ее переосмысление в контексте современности связаны с современными методами, средствами и технологиями гуманистической психологии, методами психоанализа с целью формирования целостной личности. Последние исследования и анализ публикаиий. Некоторые аспекты парадигмы самоактуализации личности и ее переосмысление в контексте современности технологий изучаются специалистами по аналитической психологии, социологии, философии, нейронауки. Цель статьи - концептуализация новых подходов к анализу самоактуализации личности и ее переосмысление в контексте современности, чтобы помочь сформировать целостную личность, сформировать себя, a, следовательно, стать такими, какими действительно хочет современное общество, а для этого следует глубже понять закономерности развития человека и общества, собственного характера, что будет способствовать поиску путей к лучшему воплощению самих себя. Задачи исследования: 1) проанализировать теоретическую парадигму Маслоу как сторонника «теории человеческого бытия» или «позитивной психологии; 2) исследовать феномен самоактуализации как парадигмы реализации своего собственного потенциала. Среди методов мы используем методы гуманистической психологии, в частности экзистенциально-гуманистического направления, которые делают выразительный акцент на гуманистических мотивах. Основная часть статьи. Представлено исследование парадигмы Маслоу как сторонника «теории человеческого бытия» или «позитивной психологии, которая развивается в быстро изменяющемся мире. Раскрыты условия становления целостной личности и путей достижения ее самоактуализации. В данной статье анализируется дополненная иерархия потребностей Маслоу, которая основывается на последних научных исследованиях и является той основой, которая поможет человеку разобраться в своих поведенческих моделях и понять, как настоящий образ жизни помогает росту и трансцендентности. Раскрыт феномен самоактуализации как парадигмы реализации своего собственного потенциала, для чего человеку необходимо прежде всего удовлетворить базовые потребности - безопасности, стабильности, определенности,

Становлення і розвиток парадигми самоактуалізації особистості та їі переосмислення у контексті сучасності 
предсказуемости, связнности, последовательности и доверия к окружающим. Выводы исследования. Доказано, что самоактуализация и трансцендентность могут существовать в полной гармонии. Выход к новым рубежам человеческой природы требует настоящего сочетания представлений о самоактуализации, что предусматривает ситуацию защищенности. Современная школа должна стать местом для формирования благоговения, самоактуализации, воспитания целостных личностей.

Ключевые слова: самоактуализация личности, Маслоу, метамотивации, креативность, высшие потребности, высшие ценности, теория «человеческого бытия», трансцендеры, здоровая самореализация

(C) The Author(s) 2021

Received date 05.06.2021

This is an open access article under

Accepted date 29.06.2021

the Creative Commons CC BY license

Published date 01.07.2021

How to cite: Лисенко С. О. Становлення і розвиток парадигми самоактуалізації особистості та iii переосмислення у контексті сучасності. Humanities studies: collection of scientific papers / Ed. V. Voronkova. Zaporizhzhia : Publishing house "Helvetica", 2021.8 (85). P. 20-28.

doi: https://doi.org/10.26661/hst-2021-8-85-02 